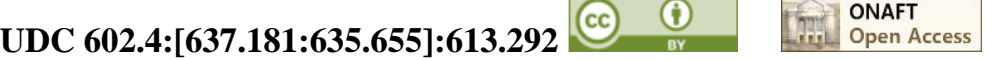 \\ DOI https://doi.org/
}

L.V. Trufkati, PhD, Associate professor, e-mail: trufkati@gmail.com

ORCID: http://orcid.org/0000-0002-6233-6533, ResearcherID: D-2876-2016

L.V. Kaprelyants, Doctor of technical sciences, Professor, e-mail: leonid@onaft.edu.ua ORCID: https://orcid.org/0000-0003-2136-5669, ResearcherID: N-7088-2015, SCOPUS: Author ID 55782222900

L.G. Pozhitkova, PhD, Assistants, professor, e-mail: pozhitkova@ukr.net ORCID: http://orcid.org/0000-0002-7652-3305, ResearcherID: N-3485-2016

Department of Biochemistry, Microbiology and Physiology of Nutrition Odessa National Academy of Food Technologies, 112, Kanatna Str., Odessa, 65039, Ukraine

\section{BIOTECHNOLOGY OF SOYA MULTI-COMPONENT FUNCTIONAL INGREDIENTS}

\begin{abstract}
The materials of the article present analytical and scientific-practical results of research of soy multi-component functional ingredients. Soy extract (or soy milk) is a valuable and cheap source of protein and other nutritious and biologically active components, like lipids, vitamins, mineral elements, isoflavones, flavonoids, saponins etc. But the presence of indigestible oligosaccharides and a bean flavor limit the consumption of soy milk. The soy oligosaccharides are known to be prebiotic for intestinal microbiota, particularly for probiotic microorganisms that hydrolyze them with the enzyme $\alpha$-galactosidase. Isoflavones are known as phytoestrogens since they are similar to human estrogen in structure and function, and are recommended to prevent many hormonedependent diseases. In soy beans and unfermented soy products, isoflavones are present mainly as biologically inactive glycoside conjugates. Biologically active aglycones of soy isoflavones are substances that are assimilated by human organism from soy products faster and in higher amounts than their corresponding glycosides. The members of intestinal microbiota are predicted to play an important role also in the metabolism and bioavailability of isoflavones since they, synthesizing $\beta$-glycosidase, cause hydrolysis of glycoside components, thus releasing the bioavailable and biologically active form of aglycone. In this work, we estimated the potential of some Lactobacillus and Bifidobacterium strains to synthesize $\alpha$-galactosidase and $\beta$-glycosidase, and to reduce respectively the amount of galactooligosaccharides and to convert isoflavones into their active forms, when growing in soy milk. Simultaneously, the profile of soy milk fermentation by the chosen probiotics was studied, as well as the proteolytic activity and accumulation of lactic acid by those probiotics, $i$. e. the possibility to produce soy-based polyfunctional fermented food products was investigated.

Key words: fermentation, soy milk, lactobacilli, bifidobacteria, probiotics, oligosaccharides, isoflavones,
\end{abstract} $\alpha$-galactosidase, $\beta$-glycosidase.

\section{Introduction}

Recently, the problem of gastrointestinal diseases of various causes is very acute in Ukraine. The decrease in level of probiotic strains, particularly bifidobacteria and lactobacilli, results in disorders in digestion processes and many essential biochemical processes in the organism. This, in turn, result in disorder in the organism's general condition, and in its decreased resistance to pathogenic and opportunistically pathogenic microorganisms. The main causes of this are an uncontrolled use of antibiotics and low-quality dietary supplements, poor and improper nutrition, bad habits, psychoemotional overstrain, rapid pace of life [1-4].

The main way to prevent and treat gastrointestinal diseases caused by dysbacteriosis is to use preparations, functional ingredients and products that contain probiotics. Use of probiotics allows to improve (and sometimes to restore) the microbiota of human intestine and mucous membranes. This results in improvement of general health condition and prevents development of a wide range of chronic diseases.

It is important to notice that modern biotechnology of making complex probiotic preparations is based on separate cultivation of various strains and their further combination in various ratios. Considering the symbiosis of useful bacterial microbiota in the human organism, growth features of the used cultures (sensitivity to oxygen, production of vitamins, requirement of certain nutrients etc.), requirement of nutrients when recovering in the enteral medium, it is topical and reasonable to use combined deep cultivation of the strains and to use a prebiotic component (thus making a synbiotic product) with a significant clinical effect.

Soy products draw high attention not only as sources of very important nutrients, but also as active carriers of probiotic microorganisms, prebiotics and synbiotics. Fermentation of soy extracts (soy milk) by lactobacilli and other useful microorganisms allows not only to increase their nutritional value, but also to enhance it via enrichment with biologically active compounds.

The mechanism of medical and preventive action of probiotics is complex and caused not only by high content of viable cells and accumulation of their extracellular metabolites (that enhance the probiotic effect), but also by other positive effects on the consumers' health. Today, numerous abilities of probiotic microorganisms are known: they decrease the level of low-density lipoprotein cholesterol (LDL cholesterol) and the symptoms of lactose intolerance, improve the bioavailability of mineral elements (particularly, calcium, magnesium, and zinc) and isoflavones, availability of proteins, intestinal health, support the immune system, demonstrate antioxidant, anticarcinogenic and antihypertensive activity, etc. As the results of clinical investigations have shown, they promote the multiplication of beneficial bacteria, and produced metabolites decrease the risk of gastrointestinal diseases, some types of cancer, cardiovascular diseases $[2,4-7]$. 
New experimental data show a potential positive role of probiotics in multi-factor diseases, including those caused by deviations in life style and unbalanced diet. Factors like stress, overtime work, smoking, combined with high-calorie and low-nutrient diet, can result in disorders of homeostatic mechanisms and impairment of the organism's natural protection. This promotes the development of metabolic syndrome which is a combination of risk factors for cardiovascular diseases (CVD), such as abdominal obesity, atherogenic dyslipidemia, increased blood pressure, insulin resistance, chronic lowgradation proinflammatory processes and prothrombotic changes [8].

Therefore, based on the consumers' concern, investigations focused on making new functional fermented soy products are topical, as well as those focused on studying biochemical processes occurring during fermentation by probiotic microorganisms, on studying the composition and properties of finished products.

\section{statement \\ Analysis of literature data and problem}

Soybean is a plant from a genus of herbaceous plants of Fabaceae family (legumes). Members of this family have characteristically high effectiveness of protein synthesis, and soybean additionally has that of fat synthesis. The phenomenon of soybean is its unique chemical composition. Its seeds contain 38 to $40 \%$ of protein, $18-20 \%$ of fat, $25-30 \%$ of carbohydrates, $4 \%$ of mineral substances and $10 \%$ of water. The soybean protein has a well-balanced amino acid composition and high availability, which makes it comparable to animal protein [9-10]. The availability of soybean protein (70\%) is lower than that of animal protein (meat and fish 9395\%, milk and eggs 96-98\%), but disintegration of cellular structures of soybeans and extraction of proteins them during processing increases the soybean protein availability to $91-94 \%$. And as for the dietetic properties, the soybeans lack what is referred to as hyperlipidemic effect, i. e. they do not cause hyperlipemia (increased content of lipids in blood), and decrease the blood cholesterol level (which is important in treating some cardiovascular and cancer diseases) and stimulate healing processes in gastric ulcer. They are also used in preventing hormonal disorders [9, 11-13].

In addition to protein, soybeans are a good source of high-quality lipids. Soybean oil contains about $85 \%$ of polyunsaturated fatty acids (of which linoleic acid accounts for $8 \%$, linolenic acid for $54 \%$ and oleic acid for $23 \%$ ), and only about $15 \%$ of saturated fatty acids (of which $11 \%$ of palmitic acid and $4 \%$ of stearic acid). Soybean is a source of lipoid substances - the phospholipids, namely lecithin, cephalin, sphingomyelin etc.

The soybean lecithin is considered as the most high-quality one, because it is choline-rich and is a complex of natural phospholipids (has $30 \%$ of phosphatidylcholine, $23 \%$ of phosphatidyl ethanolamine, and about $13 \%$ of phosphatidylinositol). Consuming soybean oil regulates lipid and cholesterol metabolism, enhances antioxidative processes in the organism, stimulates repair of cell membranes, promotes strengthening of walls of blood vessels, and therefore is recommended for treat- ment of diabetes mellitus, kidney stone disease, digestion disorders, brain and nervous system diseases, obesity, endocrine disorders $[9,11,12,14]$.

Soybeans contain $27-35 \%$ of carbohydrates. Of them, soluble carbohydrates account for about $15 \%$ : sucrose for $4-6 \%$, stachyose $-5 \%$, raffinose $-1-2 \%$, starch - 1-3\%, monosaccharides (glucose, arabinose, ribose) less than $1 \%[9,11]$. Special focus must be made on soybean oligosaccharides - stachyose and raffinose - which are not hydrolyzed and assimilated by humans, they enter the intestine unchanged and perform a prebiotic function there, being a substrate for bifidobacteria $[9,11,15]$.

Polysaccharides account for about $15 \%$ of soybean dry matter: pectins for $30 \%$, cellulose $-20 \%$ and hemicelluloses (arabinoglycans, arabinans, acidic polysaccharides) $-50 \%$. They belong to the dietary fiber group, and they stimulate the intestinal peristalsis, form the stools, absorb toxic and radioactive substances, cholesterol and bile acids. Regular consumption of polysaccharides by humans is a reliable prevention of cardiovascular and cancer diseases, diabetes mellitus, gallstone disease, obesity and dysbacterioses $[9,11]$.

High content of vitamins of $\mathrm{B}$ group, $\mathrm{E}$ and $\mathrm{K}$ in the soybeans also should be noted. These vitamins are required for normal functioning of cardiovascular, circulatory, gastrointestinal, nervous and humoral systems. Soybean is also rich in such mineral elements as potassium, phosphorus, calcium, magnesium, iron, selenium. Additionally, not only the amount of a given element is important, but also the ratio between different elements. Soybean is known to have an almost ideal ratio of the following elements: $\mathrm{Ca}$ to $\mathrm{Mg}, \mathrm{Ca}$ to $\mathrm{P}, \mathrm{Na}$ to $\mathrm{K}[9,11]$.

The soybean biologically active components important for regulation of metabolism also includes flavonoids, isoflavones (1.261 to $3.886 \mathrm{mg} / \mathrm{g}$ of soybean mass), saponins ( $0.5 \%$ of soybean mass), phytosterols, protease inhibitors (5 to $10 \%$ of protein mass), lectins (1$3 \%$ of soybean mass), phytates (1-1.5\% of soybean mass) etc. $[9,11,16]$.

Flavonoids possess potent antioxidative properties and are used to prevent cardiovascular diseases and metabolic disorders. Their immunostimulating, radioprotective and anticancer activity is also known. Saponins are glycosides that do not contain nitrogen in their molecules. The soybean saponins have been shown to possess antitumor, antioxidative, bactericidal, and immunostimulating activity. Phytosterols demonstrate a hormone-like action, similar to that of female sex hormones $[9,11,12$, 16-18].

Isoflavones belong to phytoestrogens group, they possess a stabilizing effect on the organism's hormonal state, compensating the deficiency of sex hormones or decreasing their production by competitive binding to the cell receptors. Also they prevent hormonedependent breast and prostate cancer and the symptoms of menopause and premature ageing, especially in women after menopause. Additionally, they regulate glucose level in blood, interfere with blood supply to cancer cells (thus stopping their growth), possess chemoprotective properties, support the bone tissue, decrease levels of total cholesterol and LDL cholesterol in blood, prevent cardiovascular diseases etc. [9, 19, 20].

Protease inhibitors, lectins, phytates and lipoxy- 
genase are antinutrient factors of soybeans. But under proper technological processing they are easily inactivated, since they are sensitive to hydrothermal treatment $[9$, $12,13]$.

Thus, studying the composition of soybeans showed them to be an abundant source of biologically active substances, many of them are functional, which makes the soybean products an important part of functional food products and nutriceutics $[9,21]$. But soybean-based products usually are consumed by Asian population, because the bean flavor and intestinal disorder associated with presence of indigestible oligosaccharides limit their popularity. This problem can be resolved by using soybean extract fermented by lactic acid bacteria.

During the process of obtaining soybean extract, the bulk of biologically active soybean substances enters the extract, the antinutrient components are disrupted and the bean flavor significantly decreases. Fermentation of soybean extract by lactic acid bacteria promotes hydrolysis of soybean oligosaccharides by the enzyme $\alpha$ galactosidase, i. e. it prevents intestinal disorder after consumption of such products. Also it helps to get rid of the bean flavor, increases the availability of nutrients (particularly proteins and mineral substances), improves the bioavailability of isoflavones, activates the immune system, decreases cholesterol level, inhibits development of pathogenic microorganisms in the intestine etc. Fermented soybean extract is a carrier of probiotic, antioxidative, protease, $\beta$-glycosidase and $\alpha$-galactosidase activity $[6,9,22]$.

Thus, soymilk fermented by probiotic microorganisms can be converted into a polycomponent biologically active functional food system that makes a positive impact on human health.

\section{Purpose and objectives of research}

Considering the nutrition and biological value of soybean extract, our investigations comprised obtaining polyfunctional ingredients from soybeans using a consortium of lactic acid bacteria and bifidobacteria.

In order to reach the mentioned goal, the following tasks were set:

- select the technological parameters to obtain a soybean fermented drink using lactic acid bacteria and bifidobacteria;

- study the fermentative activity of the cultures in question and the biochemical changes in the process of fermentation;

- determine the biochemical and microbiological indicators of the obtained drink.

\section{Materials and methods of investigation}

Cultures from the collection of biochemistry, microbiology and nutrition physiology department of ONAFT were used in this investigation: Bifidobacterium longum Я3, Bifidobacterium adolescentis C52, Lactobacillus plantarum $B-578$.

Soy milk was obtained using a technology which includes the following operations: shelling of soybeans, wet-heat treatment for $5 \mathrm{~min}$ at $120^{\circ} \mathrm{C}$, in $0.5 \%$ solution of $\mathrm{Na}_{2} \mathrm{CO}_{3}$ with a hydromodule of $1: 6$, removal of $\mathrm{Na}_{2} \mathrm{CO}_{3}$ solution, disintegration, aqueous extraction at a hydromodule of 1:5, filtration, introducing additional components recommended to give the extract a better flavor (salt, sugar, vanillin), pasteurization at $90^{\circ} \mathrm{C}$ for 15 min (the parameters appropriate for the high protein content in the soy milk), cooling down to $2-6^{\circ} \mathrm{C}$ and storage for no longer than 36 hours [9].

This technology allows to obtain a sweet drink with a pleasant flavor, intensely cream-white in color, with a faint pleasant odor. The wet-heat treatment means elimination of side substances giving the soymilk foreign flavors and odors (like lipoxygenase) from the soybeans, and also elimination of antinutrient factors like phytates, trypsin inhibitors and lectins. During the aqueous extraction, mainly water-soluble soybean components enter the milk, and also partly the poorly water-soluble polysaccharides and other components.

The process of soy milk fermentation was conducted at $37^{\circ} \mathrm{C}$ with introducing the laboratory starter in an amount of $3 \%$ of the milk mass, intended to make an initial concentration of probiotic microorganisms no less than $10^{6} \mathrm{CFU} / \mathrm{ml}$.

The titer of the cultures was determined by inoculation of tenfold dilutions of the product into special selective media for bifidobacteria and lactobacilli: cornlactose medium with neomycin and MRS, respectively. After incubation at $37 \pm 1^{\circ} \mathrm{C}$ for 48 hours typical colonies were counted. In addition to cultural traits of obtained colonies, the morphology of microorganisms from them was also studied.

Changes of active acidity were controlled in the soy milk fermentation process every 3 hours using a $\mathrm{pH}-$ meter. The activity of acid production in the studied samples was determined by titrimetric method every 3 hours as well. The titration was made with 0.1 mole $\mathrm{NaOH}$ solution with phenolphthalein as indicator. The titrated acidity was calculated according to the formula:

$$
{ }^{\circ} \mathrm{T}=\mathrm{A} \times \mathrm{K} \times 10
$$

where $\mathrm{A}$ is the number of milliliters of 0.1 molar $\mathrm{NaOH}$ used to titrate $10 \mathrm{ml}$ of culture liquid, $\mathrm{K}$ is a correction coefficient to the 0.1 molar $\mathrm{NaOH}$ solution, ${ }^{\circ} \mathrm{T}$ is a value expressed in Turner degrees.

Both in unfermented soy milk and after fermentation, carbohydrates were separated with a highperformance liquid chromatography (HPLC). The eluent consisted of $75 \%$ of acetonitrile and $25 \%$ of distilled water, and was maintained at a flow speed of $1 \mathrm{ml} / \mathrm{min}$ isocratically. An injected volume of $20 \mathrm{ml}$ was used both for samples and standards. The retention time of standards for raffinose, stachyose and sucrose was 11.4, 19.1 and $7.8 \mathrm{~min}$, respectively. Standard initial solutions of raffinose $(2.53 \mathrm{~g} / 100 \mathrm{ml})$, stachyose $(2.03 \mathrm{~g} / 100 \mathrm{ml})$ and sucrose $(2.53 \mathrm{~g} / 100 \mathrm{ml})$ were used to prepare a standard calibration curve. The concentration of oligosaccharides was determined using the standard curve and expressed in milligrams of sugar per $100 \mathrm{ml}$ soy milk [23].

Sugars for this were extracted using the method described above [24] with some changes: in order to remove proteins, $3 \mathrm{ml}$ of each sample were centrifuged at $14000 \times \mathrm{g}$ for $30 \mathrm{~min}$, followed by filtration using a 0.2 $\mu \mathrm{m}$ membrane filter. 
The amount of lactic acid was determined by titrimetric method, followed by conversion [25].

Proteolytic activity of starter cultures on soy milk was controlled by the dynamics of amino nitrogen in the fermentation process. This dynamics was determined by colorimetry and also by accumulation of free $\mathrm{NH}_{3}$ groups measured using the method of o-phthalic dialdehyde. In order to determine free $\mathrm{NH}_{3}$ groups, $100 \mu \mathrm{l}$ of fermented soy milk sample was added to $750 \mu \mathrm{l}$ of o-phthalic dialdehyde, exposed for $2 \mathrm{~min}$ at room temperature, then the optical density was measured with a spectrophotometer at $340 \mathrm{~nm}$. The proteolytic activity in this was determined as the absorption of free amino groups measured at $340 \mathrm{~nm}$. Relative level of proteolysis was determined as the difference between the proteolytic activity in fermented soy milk and that of unfermented milk [26, 27].

In order to determine $\alpha$-galactosidase and $\beta$ glycosidase activity, samples were taken every 3 hours for 12 hours of soy milk fermentation by the probiotic cultures. Then, they were centrifuged at $4000 \times \mathrm{g}\left(4^{\circ} \mathrm{C}\right)$ for 30 minutes to obtain cellular enzyme extracts, which were analyzed for the activity of both enzymes according to a method described above [24]. For this, $60 \mu \mathrm{l}$ of extracellular enzymatic extract were mixed with $120 \mu 1$ of 5 $\mathrm{mM}$ corresponding specific substrates pNP $\alpha \mathrm{Gal}$ (pnitrophenyl $\alpha$-D-galactopyranoside) or pNP $\beta$ Glu (pnitrophenyl $\beta$-D-glucopyranoside) and incubated at $37^{\circ} \mathrm{C}$ for $30 \mathrm{~min}$. The reaction was stopped by adding $120 \mu \mathrm{l}$ of cold $0.2 \mathrm{M}$ sodium carbonate. The amount of released $\mathrm{p}$ nitrophenol was measured using a spectrophotometer at 405 or $420 \mathrm{~nm}$, respectively, using a linear calibration method obtained with p-nitrophenol in the same conditions. One unit of enzyme's activity was taken by the amount of the enzyme that released one micromole of $\mathrm{p}$ nitrophenol from the substrate $\rho$ NPG per milliliter per minute, in corresponding conditions. The specific activity was expressed in units (U) of activity of both enzymes per milligram of protein $[28,29]$.

Isoflavones were extracted with aqueous solutions of polar solvents. A $70 \%$ aqueous solution of ethanol or $80 \%$ aqueous solution of methanol was used for this. Duration of extraction varies from 2 to 24 hours and depends on the temperature, which can be in the range from room to $80^{\circ} \mathrm{C}$. But, as some authors state, high temperatures are undesired for extraction, because they increase the likelihood of hydrolysis of bonds of carbohydrate esters, which, in turn, can result in significant changes of the isomeric composition of isoflavones [28, 30].

Isoflavones were determined quantitatively using a gas-liquid chromatograph "Knauer" (Germany) with SGX $-\mathrm{C}_{18}(3 \times 250 \mathrm{~mm})$ column made by "Separon" company (Czechoslovakia), which has a reentrant phase and a mobile phase "water : polar solvent (methanol)" in a gradient of solvent's concentration 30 to $90 \%$, the detector was UV. The output components were registered at $220 \mathrm{~nm}[28,30]$.

Results and their discussion

In the process of fermentation, the changes of active, titrated acidity and the number of cells of probiotic microbes were controlled (fig. 1, 2).

The results show that the competitive relations between lactobacteria and bifidobacteria change fundamentally when they are cultivated together on soy milk, compared to cultivation on cow milk. Lactobacillus plantarum is known to be a potent and fast acid producer when growing on cow milk. It is homofermentative and accumulates $90 \%$ of lactic acid, ferments milk within 3-5 hours, the critical acidity in this can be $200-250^{\circ} \mathrm{T}$. For bifidobacteria, milk is not a natural habitat, and they develop there very slowly, the main reasons of this are the dissolved oxygen, ability to assimilate casein only after its partial hydrolysis, low phosphatase activity etc. Additionally, bifidobacteria do not develop at the medium's $\mathrm{pH}$ below 4.5, therefore Lactobacillus plantarum outcompetes them when grown together on cow milk.

The titrated acidity elevation rate and active acidity decrease rate in different phases of fermentation are different in cow milk and soy milk. When cultivating the symbiotic starter on cow milk, the adaptation phase takes about 6 hours, then the acidity increases, with its rate increasing towards the end of the fermentation process. In this case, the main participants of the fermentation are lactobacilli, bifidobacteria develop only during the initial stage, then their growth slows down because of unfavorable conditions: elevated acidity, absence of growth factors, lack of energy-yielding material.

When developing on soy milk, adaptation of probiotic cultures takes 3-3.5 hours, and the whole fermentation process lasts for 8-10 hours depending on the organoleptic properties (density, viscosity etc.) of the curd. For example, in 9 hours of fermentation $\mathrm{pH}$ is 5-5.3 at average, titrated acidity is $53-62^{\circ} \mathrm{T}$. Such indexes are indicative of a milder and more delicate flavor of finished product and of the possibility to extend the storage life of fermented soy products with retention of their probiotic properties compared to sourmilk drinks (fig. 1)

Certain symbiotic relations between the chosen 
strains of bifidobacteria and Lactobacillus plantarum have been shown to form in the soy milk, which allows to obtain high titers of probiotic cultures in the finished product, notably with predominance of bifidobacteria. For example, in the case of combination of Lactobacillus plantarum B-578 with Bifidobacterium longum Я3 after 9 hours of fermentation the number of cells was $8 \cdot 10^{7}$ to $10 \cdot 10^{7} \mathrm{CFU} / \mathrm{ml}$ and $7 \cdot 10^{8}$ to $9 \cdot 10^{8} \mathrm{CFU} / \mathrm{ml}$, respectively, while in the case of combination of Lactobacillus plantarum B-578 with Bifidobacterium adolescentis C52 there was $1 \cdot 10^{8}$ to $3 \cdot 10^{8} \mathrm{CFU} / \mathrm{ml}$ and $2 \cdot 10^{9}$ to $5 \cdot 10^{9}$ $\mathrm{CFU} / \mathrm{ml}$, respectively (fig. 2).

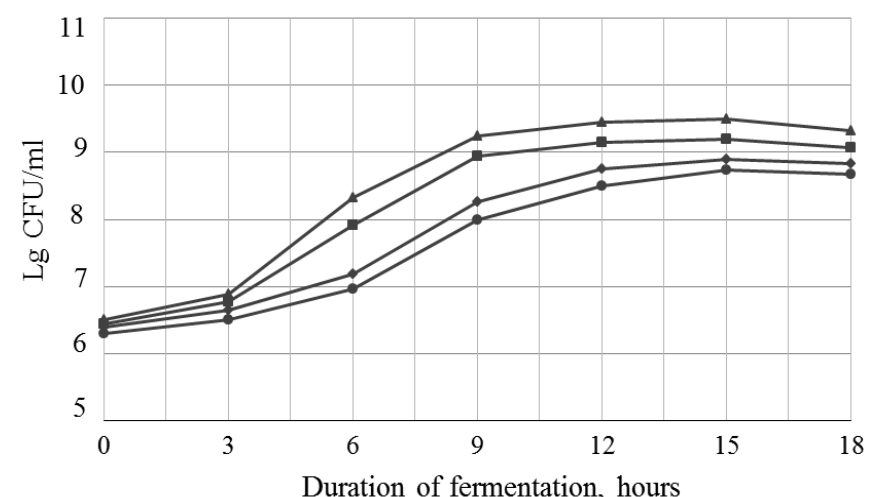

$\rightarrow$ L. plantarum + B. longum

+ B. longum + L. plantarum

$\rightarrow$ L. plantarum + B. adolescentis + B. adolescentis + L. plantarum

Fig. 2. Dynamics of accumulation of cells by probiotic cultures in a combined cultivation

This ratio between lacto and bifidobacteria developing in the soy milk can be explained as follows. Lactobacillus plantarum is known to ferment amygdalin, cellobiose, fructose, glucose, galactose, lactose, maltose, salicin, sucrose, and trehalose. Some strains ferment glycogen (usually poorly) and melibiose or raffinose. In addition, lactic acid bacteria are known to be able to change their typical saccharolytic pathway depending on the sugars present in the medium. They demonstrate a significant proteolytic and lipolytic activity. They require acetate or mevalonic acid, riboflavin, calcium pantothenate, niacin and folic acid for growth, but do not require thiamine, pyridoxal, thymidine and vitamin $\mathrm{B}_{12}$ (cyanocobalamin) [31, 32].

Bifidobacterium longum had been isolated from feces of adult human and babies, its range of hydrolyzed sugars includes lactose, galactose, sucrose, fructose, maltose, stachyose, raffinose, ribose, xylose and other sugars, which indicates that the bacterium has a wide range of saccharolytic enzymes, including $\alpha$ and $\beta$ galactosidase. These bacteria require free amino acids, like cysteine, proline, serine and alanine, and also nicotinic and folic acids to be present in the medium for growth. B. longum possesses a good proteolytic activity $[33,34]$. Thus, soy milk contains enough readily available energy sources for development of B. longum, therefore, in combination with Lactobacillus plantarum it develops more actively.

Bifidobacterium adolescentis had been isolated from feces of an adult human, it has the most active saccharolytic properties among all bifidobacteria, it can assimilate a broad range of carbohydrates and even polysaccharides. It requires riboflavin, pyridoxine, thiamine, calcium pantothenate, nicotinic acid, alanine, lysine, serine, proline, glutamic and aspartic acids to be present in the medium for growth. At the same time it has a high proteolytic activity [33-36]. This culture has been shown to develop best in soy milk, inhibiting the growth of Lactobacillus plantarum.

Among other growth conditions, lactic acid bacteria require a source of readily utilized energy carbohydrates. Soy milk contains about 3\% of carbohydrates. The carbohydrate composition of soy milk is represented mainly by galactooligosaccharides like raffinose $(1.5 \%)$, stachyose $(4.3 \%)$ and sucrose (4.5\% of dry matter). Additionally, soy milk contains minor amounts of monosaccharides like arabinose and glucose (about $0.07 \%$ ).

This carbohydrate composition is a natural medium for development of bifidobacteria, since they can synthesize $\alpha$-galactosidase in significant amounts to hydrolyze soy oligosaccharides, but this medium is insufficient for Lactobacillus plantarum. This is why studying utilization of sugars and accumulation of lactic acid during soy milk fermentation was of concern. Data on utilization of soy oligosaccharides - stachyose, raffinose and sucrose - by lactobacilli and bifidobacteria after 10 hours of fermentation are presented here. It should be noted that the concentrations of oligosaccharides in fermented products were calculated on the basis of $14 \%$ of dry matter.

Studying the carbohydrate composition of soy milk before and after fermentation showed that Lactobacillus plantarum only very slightly utilized stachyose but decreased the amount of raffinose by $15 \%$ (explained by insufficient synthesis of $\alpha$-galactosidase by this culture) and significantly decreased the amount of sucrose - by $56 \%$.

Both species of bifidobacteria demonstrated a high $\alpha$-galactosidase activity. Fermentation of soy milk by $B$. adolescentis for 24 hours resulted in total hydrolysis of oligosaccharides. The highest $\alpha$ galactosidase activity was demonstrated by $B$. longum: after 10 hours of fermentation after reaching pH 5.2 the amount of raffinose and stachyose was decreased by $73 \%$ and $56 \%$, respectively. B. adolescentis utilized oligosaccharides more poorly: their amounts decreased by $54 \%$ and $52 \%$, respectively. Additionally, the results of utilization of soy galactooligosaccharides were confirmed by studying the dynamics of $\alpha$-galactosidase activity of probiotic cultures during combined cultivation on soy milk, presented on fig. 4 . In both combinations $(L$. plantarum with $B$. adolescentis and L. plantarum with $B$. longum), their $\alpha$-galactosidase activity increased dramatically during all 12 hours of cultivation. In this, after the lag phase (the phase of adaptation) the enzymatic activity of $L$. plantarum with $B$. longum exceeded that of $L$. plantarum with $B$. adolescentis by $20 \%$ or more. For example, in 12 hours of fermentation the $\alpha$-galactosidase activity of $L$. plantarum with $B$. longum reached $98 \mathrm{U} / \mathrm{mg}$, while that of L. plantarum with $B$. adolescentis was no higher than $78 \mathrm{U} / \mathrm{mg}$ (fig. 3). In addition, bifidobacteria can utilize $\alpha-1,2-$ glycosidic bonds in the sucrose molecule. For example, after cultivation of $B$. adolescentis the amount of sucrose decreased by $8 \%$, and after cultivation of B. longum 


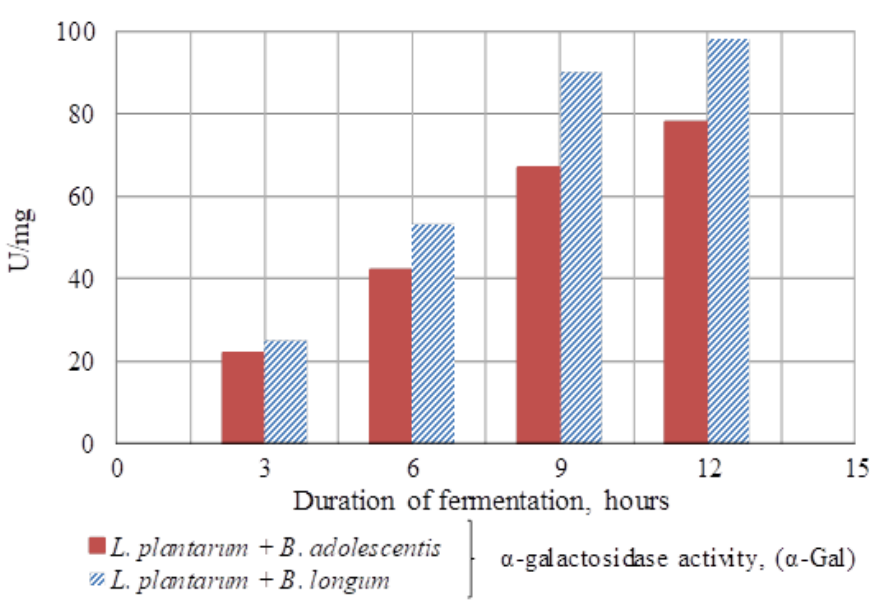

Fig. 3. Dynamics of $\alpha$-galactosidase activity of probiotic cultures in joint cultivation in soy milk at $37^{\circ} \mathrm{C}$

by $10 \%$.

Thus, it should be noted that fermentation of soy milk by bifidobacterial starters decreases the content of galactooligosaccharides significantly, i. e. prevents intestinal disorders, distension, meteorism in consumers. At the same time, glalctooligosaccharides are prebiotics that stimulate the growth and development of both starter cultures of bifidobacteria and beneficial intestinal microbiota.

During cultivation of probiotic cultures, the main metabolites are organic acids, especially lactic and acetic acid. Studying accumulation of lactic acid by the starter microorganisms during soy milk fermentation in comparison with cow milk has shown that accumulation of lactic acid is by $58 \%$ less than that on cow milk.

This significant difference in lactic acid accumulation by starter microorganisms in soy milk and cow milk with minor difference in acidity can be explained by the composition of starters, lack of easily assimilated sugars in soy milk and by the pathway used by lactobacilli and bifidobacteria to convert sugars. $L$. plantarum is an active acid producer, it ferments by glycolytic pathway where the main metabolite is the lactic acid. Bifidobacteria ferment sucrose, glucose, fructose, stachyose, maltose, galactose, lactose by "bifidic pathway" to produce mainly acetic and lactic acid in molar ratio $3: 2$, and also can produce acetate and formate [37, 38]. And since bifidobacteria predominate during combined cultivation on soy milk, minor accumulation of lactic acid is observed with a rapid elevation of acidity.

The proteolytic activity of starters is one of the most important criteria when selecting starter cultures in making sourmilk dairy. This is one of the most important properties of lactic acid bacteria which characterizes their ability to digest milk proteins to produce simpler nitrogen-containing compounds: peptones, peptides, free amino acids etc., since most of them has a high requirement of growth factors like peptides and amino acids, and the content of these factors in the original raw material is too low to provide their desired growth. Therefore, lactobacteria and bifidobacteria have a complex system of proteases and peptidases which allows them to utilize milk or soy protein as the source of amino acids and nitrogen. Various species of lactic acid microorganisms have different proteolytic activity, even strains with different activity appear within one species. For example, among lactic acid bacteria the most active are Lactobacillus bulgaricus and Lactobacillus plantarum $[37,39]$. Bifidobacteria are also known to be rather active protein digesters, except for $B$. bifidum which hydrolyzes protein very slightly $[33,40]$.

The proteolytic activity of starter cultures on soy milk, besides the ability to release free $\mathrm{NH}_{3}$ groups, was also controlled by the dynamics of amount of nonprotein nitrogen during fermentation. Before fermentation, the soy milk contained about $4.5 \mathrm{mg} / \mathrm{ml}$ of non-protein nitrogen, and after 3-4 hours of fermentation its amount decreased by $35-40 \%$ at average, and further changes of amine nitrogen concentration in the mixture depended on the bifidobacterial strain used in the starter (fig. 4).

The presented data show that the proteolytic activity of studied cultures during soy milk fermentation depends on the strain and duration of fermentation. However, both combinations of probiotic cultures reached their maximum proteolytic activity after 6 hours of soy milk fermentation, then it began to decline slightly and in 12 hours of fermentation reached $80 \%$ of the maximum level in Lactobacillus plantarum B-578 with Bifidobacterium adolescentis $\mathrm{C} 52$ and $70 \%$ in Lactobacillus plantarum B-578 with Bifidobacterium longum Я3. This is confirmed also by the dynamics of amine nitrogen content (fig. 4).

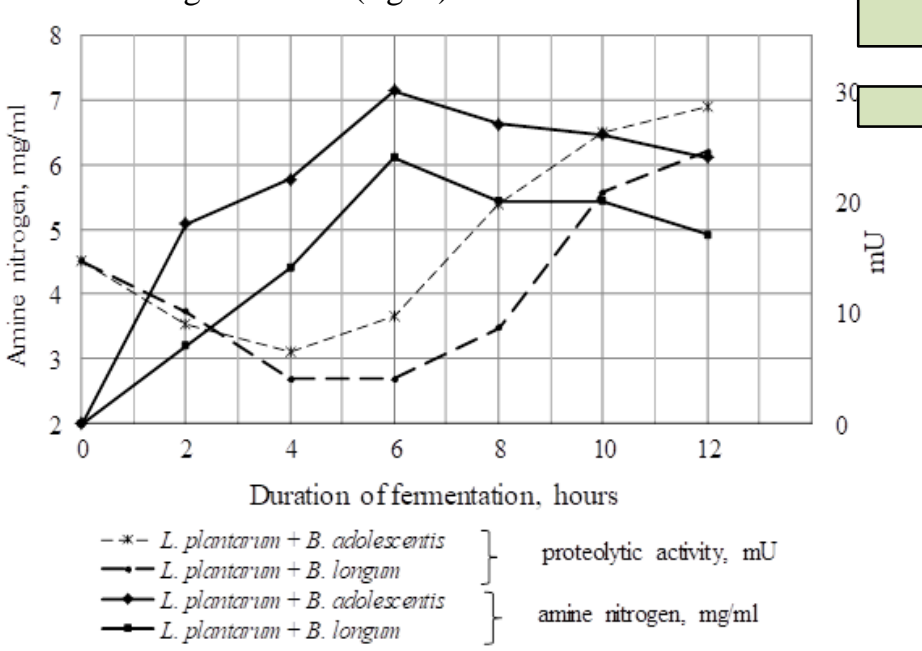

Fig. 4. Dynamics of proteolytic activity and content of amine nitrogen during soy milk fermentation by a culture of Lactobacillus plantarum B-578 in combination with bifidobacteria

The amount of amine nitrogen does not change from 4 to 6 hours of soy milk fermentation by Lactobacillus plantarum B-578 with Bifidobacterium longum Я3, then towards 8 hours of fermentation it begins to increase, and by the end of the fermentation process it is about $125 \%$ of the initial value. When the symbiotic starter of Lactobacillus plantarum B-578 with Bifidobacterium adolescentis $\mathrm{C} 52$ was used, the content of amine nitrogen begins to increase after only 5 hours from the start of the process, then after 7 hours it is equal to the initial value, and in 12 hours it is more than $150 \%$ of the initial value (fig. 4). This distinguishes $B$. adolescentis from other studied strains of bifidobacteria, because it 
has the highest proteolytic activity. Consequently, the high proteolytic activity of bifidobacteria, in addition to their ability to metabolize soy oligosaccharides, explains their active growth and development on soy milk.

It can be said that the correlation between growth of the cultures and their proteolytic activity demonstrates a positive impact of proteolysis of soy proteins on accumulation of Lactobacillus plantarum B-578 and Bifidobacterium adolescentis C52 biomass.

Isoflavones are a part of diphenol compounds, they are referred to as phytoestrogens because they are similar to estradiol (a human estrogen) in structure and function, although much less potent. Due to this similarity, there are numerous investigations of preventive action of soy isoflavones on many types of hormone-dependent diseases [36]. In total, 12 forms of isoflavones have been isolated from soy beans and products of their processing. They are found in 4 chemical forms, including 3 free forms called aglycones (genistein, daidzein, and glycitein) and 3 conjugated forms with each aglycone, called glycosides. Conjugated forms have an additional glucose component which can either be bonded to acetyl (6"-O-acetylglycosides) or malonyl (6"-Omalonylglycosides) groups or be free of other groups $(\beta$ glycosides, namely genistin, daidzin and glycitin). For example, in soy beans and unfermented soy products isoflavones are found mainly in the form of biologically inactive glycoside conjugates which account for 80 to 95\% of their total content [35]. The biologically active estrogen-like isoflavone compounds are aglycone configurations of genistein, daidzein and glycitein, which are faster and in greater amounts assimilated by human organism from soy products than their correspondent glycosides $[41,42]$.

The members of intestinal normal microbiota are supposed to play an important role in metabolism and bioavailability of isoflavones, since they hydrolyze glycoside components with their $\beta$-glucosidase, releasing a bioavailable and biologically active form of aglycone [43]. Methods of fermentative transformation using microbial glucosidases have an immense potential to produce biologically active aglycones by hydrolysis of sugar fragments of various glycosides in food products. The members of Bifidobacterium and Lactobacillus genera are known to contain many glycosyl hydrolases like amylase, $\alpha$ and $\beta$-glucosidase, $\alpha$ and $\beta$-galactosidase, $\alpha$-Lfucosidase, $\alpha$-L-arabinofuranosidase, and $\beta$ fructofuranosidase. These play the key role in the intestinal hydrolysis of various oligosaccharides, polysaccharides, and glycoconjugated phytochemical substances, including isoflavonic glycosides which are converted into their bioactive aglycone forms by $\beta$-glucosidase [27, 41, 44].

The $\beta$-glycosidase activity of lactobacillary and bifidobacterial consortia during soy milk fermentation at $37^{\circ} \mathrm{C}$ was determined every 3 hours (fig. 5).

Investigations showed that the $\beta$-glycosidase activity of both consortia increased rapidly from the first hours of fermentation (fig. 5). The highest activity was observed in combined cultivation of Lactobacillus plantarum B-578 with Bifidobacterium longum Я3 on soy milk, it reached its maximum in 6 hours and measured $81 \mathrm{U} / \mathrm{mg}$ of soy protein, then it slowly declined and

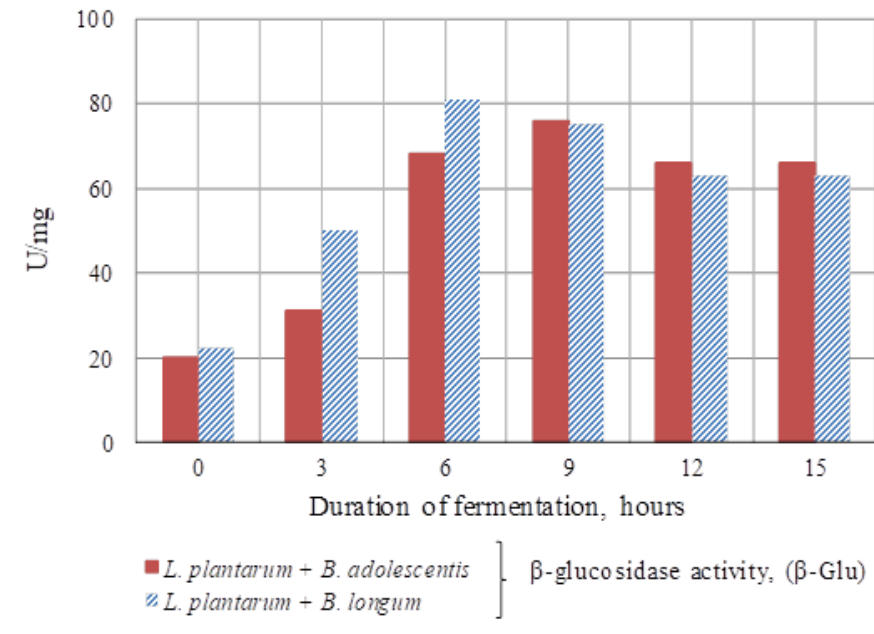

Fig. 5. Dynamics of $\beta$-glycosidase activity of probiotic cultures during joint cultivation in soy milk at $37^{\circ} \mathrm{C}$

measured $63 \mathrm{U} / \mathrm{mg}$ of soy protein after 12 hours of fermentation. The $\beta$-glycosidase activity of Lactobacillus plantarum B-578 and Bifidobacterium adolescentis C52 consortium increased more slowly and reached its maximum in 9 hours of cultivation on soy milk $(75 \mathrm{U} / \mathrm{mg}$ of soy protein), then it also began to decline and reached 66 $\mathrm{U} / \mathrm{mg}$ of soy protein after 12 hours. Thus, the elevation and decline in $\beta$-glycosidase activity of both consortia during soy milk fermentation correspond to the exponential and stationary phases of bacterial growth, respectively (fig. 5).

Of special interest were the changes in amount of isoflavonic glycosides and aglycones during soy milk fermentation by selected cultures. This amount was determined in initial soy milk and after 9 and 12 hours of fermentation. Analysis of changes in concentrations of isoflavonic glycosides and aglycones during soy ilk fermentation by selected cultures showed that decrease of concentrations of isoflavonic glycosides and increase in concentration of corresponding aglycones aligned with increase of $\beta$-glycosidase activity during soy milk fermentation by some cultures. For example, in soy milk fermented by L. plantarum B-578 c B. longum Я3 the content of daidzin, glycitin and genistin in 12 hours decreased by $93 \%, 75 \%$, and $99.6 \%$, respectively, and the corresponding aglycones increased in concentration by $278 \%, 153 \%$, and $338 \%$, respectively. During soy milk fermentation by L. plantarum B-578 with B. adolescentis $\mathrm{C} 52$, the process of conversion of soy isoflavonic glycosides into aglycones was less intensive. This can be explained by the fact L. plantarum B-578 and B. adolescentis $\mathrm{C} 52$ cultures reach their maximum $\beta$-glycosidase activity by 9 hours of fermentation, while the peak $\beta$ glycosidase activity of $L$. plantarum B-578 with $B$. longum 93 appears after 6 hours of cultivation on soy milk, and the activity itself is by $8 \%$ higher. However, in 12 hours of fermentation by L. plantarum B-578 with $B$. adolescentis $\mathrm{C} 52$ the content of daidzin, glycitin, and genistin (converted into corresponding aglycones) reached that of joint fermentation by L. plantarum B-578 with B. longum Я3: 90\%, 39\% and 98\%, respectively, of disrupted daidzin, glycitin and genistin, and 259\%, $83 \%$ and $305 \%$, respectively, of produced daidzein, glycitein, and genistein. 


\section{Conclusions}

During researches, a technological process was adjusted to obtain fermented soy product using lactic acid bacteria and bifidobacteria. Fermentative activity of studied cultures and biochemical changes in the fermentation process were studied. Biochemical and microbiological indexes of the target product were determined.

Thus, the studied consortia of probiotic cultures have been shown to develop actively on soy milk and to allow to obtain polycomponent functional ingredients. The obtained products contain high titers of probiotic cultures with predominance of bifidobacteria, have required acidity and high proteolytic, $\alpha$-galactosidase and $\beta$-glycosidase activities. This allows to eliminate the intestinal discomfort after consuming such fermented soy products, to improve their chemical composition, availability, organoleptic properties, and to increase their estrogenic activity.

In the future, introduction of probiotic microorganisms like L. plantarum B-578 with B. longum Я3 into soy extracts will provide production of functional products with high health-improving effects, especially improving the microbial balance of human gastrointestinal tract.

The plans for the future include studying the stability in storage of these fermented soy products, selecting storage duration and conditions, and manufacturing forms that will preserve their probiotic properties and biological activity.

\section{REFERENCES}

1. Kaprelyants L, Yegorova A, Trufkati L, Pozhitkova L. Functional foods: prospects in Ukraine. Food Science and Technology. 2019; 13(2):15-23. doi: https://doi.org/10.15673/fst.v13i2.1382

2. Kaprelyants L. Functional Foods and Nutraceuticals-Modern Approach to Food Science. Visnyk of the Lviv University. Series Biology. [Internet]. $2016 \mathrm{Apr}$ [cited 2020 October 14]; 1 (73):[about 441pp.]. Available at: http://nbuv.gov.ua/UJRN/VLNU_biol_2016_73_122

3. Kaprelyants L, Petrosiants A. Therapeutic and prophylactic properties of food and basics of nutrition. Odesa:Druk; 2011. ISBN 978-966-2089-28-7

4. Kaprelyants L, Iorgachova K. Funkcional'ni produkti. Odesa:Druk; 2003. ISBN 966-8099-83-4.

5. Khamagaev I, Boyarinova I, Potapchuk N. The study of the probiotic properties of combined starter culture. Technique and technology of food production. 2013; 1(28). ISSN 2074-9414.

6. Kumari A, Angmo K, Monika S, Bhalla T. Functional and technological application of probiotic L. casei PLA5 in fermented soymilk. International Food Research Journal. [Internet]. 2018 Nov [cited 2020 October 14]; 25(5):[about 21642172 pp.]. Available at: http://www.ifrj.upm.edu.my/25\%20(05)\%202018/(54).pdf

7. Lourens-Hattingh A, Viljoen B. Yogurt as probiotic carrier food. International dairy journal. 2001; 11(2):1-17. doi: https://doi.org/10.1016/s0958-6946(01)00036-x

8. Panwar H, Rashmi H, Batish V, Grover S. Probiotics as potential biotherapeutics in the management of type 2 diabetes-prospects and perspectives. Diabetes/metabolism research and reviews. 2013; 29(2):103-112. doi: https://doi.org/10.1002/dmrr.2376

9. Kaprelyants L, Shpyrko T, Trufkati L. Soy products and ingredients: chemistry, technology, use. Odesa:Druk; 2014. ISBN 978617-7054-34-3.

10. Song J, QU J, XU S. Advances in Study on Soy Peptides (end)[J]. Journal of Shandong Institute of Light Industry (Natural Science Edition). 2002; 13(2): 4-26. ISBN 400-810-9888.

11. Bultosa, G. Functional Foods: Dietary Fibers, Prebiotics, Probiotics, and Synbiotics. Reference module in Food Science. Elsevier. 2016. doi: https://doi.org/10.1016/b978-0-08-100596-5.00245-6

12. Liи K. Chemistry and nutritional value of soybean components. In Soybeans. Chemistry, Technology and Utilization. Springer Boston MA. [Internet]. 1997 Sep [cited 2020 October 14]; (1):[about 25-113pp.]. Available at: https://link.springer.com/chapter/10.1007/978-1-4615-1763-4_2

13. Carol A. The Healing Power of Soy: The Enlightened Person's Guide to Nature's Wonder. Food Paperback. $1998 ; 208$. ISBN: 10:0761514716

14. Sherstobitov V. To the question of soy milk. Dairy industry. 2003; (1):53-54. ISSN: 1019-8946

15. Kaprelyants L, Kiselyov S, Nikitina Zh. Soy isoflavones: food adaptogens with phytohormonal and antioxidant activities. Cereal products and compound feeds. 2001; 1(1):40-46.

16. Kaprelyants L, Trufkati L, Pozhitkova L. Shpyrko T, Shvets N. Biotechnological aspects of obtaining fermented soybean products with increased phytoestrogenic activity. Eastern-European Journal of Enterprise Technologies. 2020; $3(11$ (105)):77-88. doi: 10.15587/1729-4061.2020.205753

17. Tutelian V, Baturin, A, Martynchik E. Flavonoids: content in food products of consumption, bioavailability. Nutrition Issues. 2004; 73(6):43-48.

18. Karpelyants L, Kiselev S, Iorgacheva K. Soy isoflavones and prospects for their therapeutic use. Nutrition Issues. 2003; 72(4):3641.

19. Kreijkamp-Kaspers S, Kok L, Grobbee D, de Haan E. Aleman A, Lampe J, van der Schouw Y. Effect of soy protein containing isoflavones on cognitive function, bone mineral density, and plasma lipids in postmenopausal women: a randomized controlled trial. Jama. 2004; 292(1):65-74. doi: https://doi.org/10.1001/jama.292.1.65

20. Setchell K, Brown N, Desai P, Zimmer-Nechimias L, Wolfe B. Jakate A. et. al. Bioavailability, disposition, and dose-response effects of soy isoflavones when consumed by healthy women at physiologically typical dietary intakes. The Journal of nutrition. 2003; 133(4):1027-1035. doi: https://doi.org/10.1093/jn/133.4.1027

21. Mayorov A, Mironenko I, Ovsyankina N, Belov A, Elchaninov V, Koval A \& Schetinin M. Prospects for the use of soy components. Dairy industry. 2002; (1):55-57.

22. Otieno D, Ashton J, Shah N. Evaluation of enzymic potential for biotransformation of isoflavone phytoestrogen in soymilk by Bifidobacterium animalis, Lactobacillus plantarum and Lactobacillus casei. Food Research International. 2006; 39(4):394-407. doi: https://doi.org/10.1016/j.foodres.2005.08.010

23. Sumarna K. Changes of raffinose and stachyose in soy milk fermentation by lactic acid bacteria from local fermented foods of Indonesian. Malaysian Journal of Microbiology. 2008; 4(2):26-34. doi: https://doi.org/10.21161/mjm.12208

24. Scalabrini P, Rossi M, Spettoli P, Matteuzzi D. Characterization of Bifidobacterium strains for use in soymilk fermentation. International journal of food microbiology. 1998; 39(3):213-219. doi: https://doi.org/10.1016/s0168-1605(98)00005-1 
25. Chun J, Jeong W, Kim J, Lim J, \& Kim, J. Park C, Kwon D. et. al. Hydrolysis of isoflavone glucosides in soymilk fermented with single or mixed cultures of Lactobacillus paraplantarum KM, Weissella sp. 33, and Enterococcus faecium 35 isolated from humans. J Microbiol Biotechnol. 2008; 1(18):573-578.

26. Batmunkh Myagmardorj, Munkh-Erdene Purev, Batjargal Batdorj Functional properties of fermented soymilk by Lactobacillus fermentum BM-325. Mongolian Journal of Chemistry. 2018; 19(45):32-37. doi: https://doi.org/10.5564/mjc.v19i45.1087

27. Chun J, Kim G, Lee K, Choi I, Kwon G, Park J, \& Kim J. Conversion of isoflavone glucosides to aglycones in soymilk by fermentation with lactic acid bacteria. Journal of Food Science. 2007; 72(2):39-44. doi: https://doi.org/10.1111/j.17503841.2007.00276.x eroy $F$, De Vuyst L. Lactic acid bacteria as functional starter cultures for the food fermentation industry. Trends in Food Science \& Technology 2004; 15(2):67-78. doi: https://doi.org/10.1016/j.tifs.2003.09.004

28. Barrangou R, Azcarate-Peril M, Duong T, Conners S, Kelly R, \& Klaenhammer T. Global analysis of carbohydrate utilization by Lactobacillus plantarum using cDNA microarrays. Proceedings of the National Academy of Sciences. 2006; 103(10):3816-3821. doi: https://doi.org/10.1073/pnas.0511287103

29. Belkaaloul K, Chekroun A, Ait-Abdessalam A, Saidi D, \& Kheroua O. Growth, acidification and proteolysis performance of two co-cultures (Lactobacillus plantarum-Bifidobacterium longum and Streptococcus thermophilus-Bifidobacterium longum). African Journal of Biotechnology. 2010; 9(10):1463-1469. doi: https://doi.org/10.5897/ajb09.1090

30. Leroy F, De Vuyst L. Lactic acid bacteria as functional starter cultures for the food fermentation industry. Trends in Food Science \& Technology 2004; 15(2):67-78. doi: https://doi.org/10.1016/j.tifs.2003.09.004

31. Barrangou R, Azcarate-Peril M, Duong T, Conners $S$, Kelly $R, \&$ Klaenhammer $T$. Global analysis of carbohydrate utilization by Lactobacillus plantarum using cDNA microarrays. Proceedings of the National Academy of Sciences. 2006; 103(10):3816-3821. doi: https://doi.org/10.1073/pnas.0511287103

32. Belkaaloul K, Chekroun A, Ait-Abdessalam A, Saidi D, \& Kheroua O. Growth, acidification and proteolysis performance of two co-cultures (Lactobacillus plantarum-Bifidobacterium longum and Streptococcus thermophilus-Bifidobacterium longum). African Journal of Biotechnology. 2010; 9(10):1463-1469. doi: https://doi.org/10.5897/ajb09.1090

33. Biavati B, Bottazzi V, Morelli L. Probiotics and Bifidobacteria. Novara (Italy): Mofin Alce. 2001; 158

34. King R, Bignell C. Concentrations of isoflavone phytoestrogens and their glucosides in Australian soya beans and soya foods. Australian Journal of Nutrition and Dietetics. 2000; 57(2):70-78. ISSN : 1032-1322

35. Uzzan M, Abuza T. Critical issues in R\&D of soy isoflavone-enriched foods and dietary supplements. Journal of food science. 2004; 69(3):CRH77-CRH86. doi: https://doi.org/10.1111/j.1365-2621.2004.tb13345.x

36. Savijoki K, Ingmer $H$, \& Varmanen P. Proteolytic systems of lactic acid bacteria. Applied microbiology and biotechnology. 2006; 71(4):394-406. doi: https://doi.org/10.1007/s00253-006-0427-1

37. Shah N. Bifidobacteria: Characteristics and potential for application in fermented milk products. Milchwissenschaft (Germany). 1997

38. Holzapfel W, Haberer P, Geisen R, Björkroth J, \& Schillinger U. Taxonomy and important features of probiotic microorganisms in food and nutrition. The American journal of clinical nutrition. 2001; 73(2):365-373. doi: https://doi.org/10.1093/ajcn/73.2.365s

39. Poch M, Bezkorovainy A. Growth-enhancing supplements for various species of the genus Bifidobacterium. Journal of dairy science. 1988; 71(12): 3214-3221. doi: https://doi.org/10.3168/jds.s0022-0302(88)79926-9

40. Tsangalis D, Ashton J, McGill AEJ \& Shah N. Enzymic transformation of isoflavone phytoestrogens in soymilk by $\beta$-glucosidaseproducing bifidobacteria. Journal of Food Science. 2002; 67(8):3104-3113. doi: https://doi.org/10.1111/j.13652621.2002.tb08866.x

41. Setchell K, Brown N, Desai P, Zimmer-Nechemias L, Wolfe B, Brashear W. et. al. Bioavailability of pure isoflavones in healthy humans and analysis of commercial soy isoflavone supplements.The Journal of nutrition. 2001; 131(4):1362S-1375S. doi: https://doi.org/10.1093/jn/131.4.1362s

42. Setchell K. Absorption and metabolism of soy isoflavones-from food to dietary supplements and adults to infants. The Journal of nutrition. 2000; 130(3):654S-655S. doi: https://doi.org/10.1093/jn/130.3.654s

43. You H, Ahn H, Kim J, Wu Q, \& Ji G. High expression of $\beta$-glucosidase in Bifidobacterium bifidum BGN4 and application in conversion of isoflavone glucosides during fermentation of soy milk. J. Microbiology \& Biotechnology. 2015; 25(4):469-478. doi: http://dx.doi.org/10.4014/jmb.1408.08013

Л.В. Труфкаті, канд. техн. наук, доцент, e-mai: trufkati@gmaiil.com Л.В. Капрельянц, д-р техн. наук, професор, e-mail: leonid@onaft.edu.ua Л.Г Пожіткова, канд. техн. наук, асистент, e-mail: pozhitkova@ukr.net Кафедра біохімії, мікробіології та фізіології харчування Одеська національна академія харчових технологій, вул. Канатна, 112, Одеса, Украӥна, 65039

\section{БІОТЕХНОЛОГІЯ СОСВИХ БАГАТОКОМПОНЕНТНИХ ФУНКЦІОНАЛЬНИХ ІНГРЕДІЄНТІВ}

\section{Анотація}

В матеріалах статі представлені аналітичні і науково-практичні результати досліджень соєвих багатокомпонентних функціональних інгредієнтів. Соєвий екстракт (молоко) - иінне й недороге джерело білку та інших поживних і біологічно активних компонентів, таких як ліпіди, вітаміни, мінеральні елементи, ізофлавони, флавоноїд, сапоніни та ін. Але присутність олігосахаридів, щуо не перетравлюються, $і$ бобового смаку обмежує широке споживання соєвого молока. Відомо, щуо олігосахариди сої є пребіотиками для представників киикової мікробіоти, зокрема пробіотичних мікроорганізмів, які гідролізують їх, завдяки синтезу ферменту $\alpha$ галактозидази. Ізофлавони називають фітоестрогенами, так як вони структурно і функиіонально схожі на людський естроген, і рекомендують для профілактики багатьох видів гормонозалежних захворювань. У соєвих 
бобах і неферментованих соєвих продуктах ізофлавони знаходяться в основному у вигляді біологічно неактивних глюкозідних кон'югатів. Біологічно активні аглікони соєвих ізофлавонів являють собою сполуки, які з соєвими продуктами засвоюються організмом людини швидше і в більи високих кількостях, ніж їх відповідні глюкозиди. Передбачається, щчо представники кишкової мікробіоти грають важливу роль також в метаболізмі $i$ біодоступності ізофлавонів, так як вони, завдяки синтезу $\beta$-глюкозидази, призводять до гідролізу глюкозідних компонентів, вивільняючи біодоступну і біологічно активну форму аглікона. У даній роботі було оиінено потенціал певних итамів лактобацил $і$ біфідобактерій синтезувати $\alpha$-галактозидазу і $\beta$-глюкозидазу, відповідно знижувати кількість галактоолігосахаридів $і$ здійснювати біоконверсію ізофлавонів в їх активні форми при зростанні в соєвому молоці. Паралельно вивчали профіль процесу ферментації соєвого молока пробіотиками, їх протеолітичну активність, накопичення молочної кислоти, тобто можливість виробництва поліфункціональних ферментованих харчових продуктів на основі сої.

Ключові слова: ферментація, соєве молоко, лактобацили, біфідобактерії, пробіотики, ізофлавони, $\alpha$-галактозидаза, $\beta$-глюкозидаза.

1. Kaprelyants L, Yegorova A, Trufkati L, Pozhitkova L. Functional foods: prospects in Ukraine. Food Science and Technology. 2019; 13(2):15-23. doi: https://doi.org/10.15673/fst.v13i2.1382

2. Kaprelyants L. Functional Foods and Nutraceuticals-Modern Approach to Food Science. Visnyk of the Lviv University. Series Biology. [Internet]. 2016 Apr [cited 2020 October 14]; 1 (73):[about 44lpp.]. Available at: http://nbuv.gov.ua/UJRN/VLNU_biol_2016_73_122

3. Kaprelyants L, Petrosiants A. Therapeutic and prophylactic properties of food and basics of nutrition. Odesa:Druk; 2011. ISBN 978-966-2089-28-7

4. Kaprelyants L, Iorgachova K. Funkcional'ni produkti. Odesa:Druk; 2003. ISBN 966-8099-83-4.

5. Khamagaev I, Boyarinova I, Potapchuk N. The study of the probiotic properties of combined starter culture. Technique and technology of food production. 2013; 1(28). ISSN 2074-9414.

6. Kumari A, Angmo K, Monika S, Bhalla T. Functional and technological application of probiotic L. casei PLA5 in fermented soymilk. International Food Research Journal. [Internet]. 2018 Nov [cited 2020 October 14]; 25(5):[about 2164 2172 pp.J. Available at: http://www.ifrj.upm.edu.my/25\%20(05)\%202018/(54).pdf

7. Lourens-Hattingh A, Viljoen B. Yogurt as probiotic carrier food. International dairy journal. 2001; 11(2):1-17. doi: https://doi.org/10.1016/s0958-6946(01)00036-x

8. Panwar H, Rashmi H, Batish V, Grover S. Probiotics as potential biotherapeutics in the management of type 2 diabetesprospects and perspectives. Diabetes/metabolism research and reviews. 2013; 29(2):103-112. doi: https://doi.org/10.1002/dmrr.2376

9. Kaprelyants L, Shpyrko T, Trufkati L. Soy products and ingredients: chemistry, technology, use. Odesa:Druk; 2014. ISBN 978-617-7054-34-3.

10. Song J, QU J, XU S. Advances in Study on Soy Peptides (end)[J]. Journal of Shandong Institute of Light Industry (Natural Science Edition). 2002; 13(2): 4-26. ISBN 400-810-9888.

11. Bultosa, G. Functional Foods: Dietary Fibers, Prebiotics, Probiotics, and Synbiotics. Reference module in Food Science. Elsevier. 2016. doi: https://doi.org/10.1016/b978-0-08-100596-5.00245-6

12. Liи K. Chemistry and nutritional value of soybean components. In Soybeans . Chemistry, Technology and Utilization. Springer Boston MA. [Internet]. 1997 Sep [cited 2020 October 14]; (1):[about 25-113pp.]. Available at: https://link.springer.com/chapter/10.1007/978-1-4615-1763-4_2

13. Carol A. The Healing Power of Soy: The Enlightened Person's Guide to Nature's Wonder. Food Paperback. $1998 ; 208$. ISBN: 10:0761514716

14. Sherstobitov V. To the question of soy milk. Dairy industry. 2003; (1):53-54. ISSN: 1019-8946

15. Kaprelyants L, Kiselyov S, Nikitina Zh. Soy isoflavones: food adaptogens with phytohormonal and antioxidant activities. Cereal products and compound feeds. 2001; 1(1):40-46.

16. Kaprelyants L, Trufkati L, Pozhitkova L. Shpyrko T, Shvets N. Biotechnological aspects of obtaining fermented soybean products with increased phytoestrogenic activity. Eastern-European Journal of Enterprise Technologies. 2020; 3(11 (105)):77-88. doi: 10.15587/1729-4061.2020.205753

17. Tutelian V, Baturin, A, Martynchik E. Flavonoids: content in food products of consumption, bioavailability. Nutrition Issues. 2004; 73(6):43-48.

18. Karpelyants L, Kiselev S, Iorgacheva K. Soy isoflavones and prospects for their therapeutic use. Nutrition Issues. 2003; 72(4):36-41.

19. Kreijkamp-Kaspers $S$, Kok L, Grobbee D, de Haan E. Aleman A, Lampe J, van der Schouw Y. Effect of soy protein containing isoflavones on cognitive function, bone mineral density, and plasma lipids in postmenopausal women: a randomized controlled trial. Jama. 2004; 292(1):65-74. doi: https://doi.org/10.1001/jama.292.1.65

20. Setchell K, Brown N, Desai P, Zimmer-Nechimias L, Wolfe B. Jakate A. et. al. Bioavailability, disposition, and doseresponse effects of soy isoflavones when consumed by healthy women at physiologically typical dietary intakes. The Journal of nutrition. 2003; 133(4):1027-1035. doi: https://doi.org/10.1093/jn/133.4.1027

21. Mayorov A, Mironenko I, Ovsyankina N, Belov A, Elchaninov V, Koval A \& Schetinin M. Prospects for the use of soy components. Dairy industry. 2002; (1):55-57.

22. Otieno D, Ashton J, Shah N. Evaluation of enzymic potential for biotransformation of isoflavone phytoestrogen in soymilk by Bifidobacterium animalis, Lactobacillus plantarum and Lactobacillus casei. Food Research International. 2006; 39(4):394-407. doi: https://doi.org/10.1016/j.foodres.2005.08.010

23. Sumarna $K$. Changes of raffinose and stachyose in soy milk fermentation by lactic acid bacteria from local fermented foods of Indonesian. Malaysian Journal of Microbiology. 2008; 4(2):26-34. doi: https://doi.org/10.21161/mjm.12208 
24. Scalabrini $P$, Rossi M, Spettoli P, Matteuzzi D. Characterization of Bifidobacterium strains for use in soymilk fermentation. International journal of food microbiology. 1998; 39(3):213-219. doi: https://doi.org/10.1016/s01681605(98)00005-1

25. Chun J, Jeong W, Kim J, Lim J, \& Kim, J. Park C, Kwon D. et. al. Hydrolysis of isoflavone glucosides in soymilk fermented with single or mixed cultures of Lactobacillus paraplantarum KM, Weissella sp. 33, and Enterococcus faecium 35 isolated from humans. J Microbiol Biotechnol. 2008; 1(18):573-578.

26. Batmunkh Myagmardorj, Munkh-Erdene Purev, Batjargal Batdorj Functional properties of fermented soymilk by Lactobacillus fermentum BM-325. Mongolian Journal of Chemistry. 2018; 19(45):32-37. doi: https://doi.org/10.5564/mjc.v19i45.1087

27. Chun J, Kim G, Lee K, Choi I, Kwon G, Park J, \& Kim J. Conversion of isoflavone glucosides to aglycones in soymilk by fermentation with lactic acid bacteria. Journal of Food Science. 2007; 72(2):39-44. doi: https://doi.org/10.1111/j.17503841.2007.00276.x

28. Leroy F, De Vuyst L. Lactic acid bacteria as functional starter cultures for the food fermentation industry. Trends in Food Science \& Technology 2004; 15(2):67-78. doi: https://doi.org/10.1016/j.tifs.2003.09.004

29. Barrangou R, Azcarate-Peril M, Duong T, Conners S, Kelly R, \& Klaenhammer T. Global analysis of carbohydrate utilization by Lactobacillus plantarum using cDNA microarrays. Proceedings of the National Academy of Sciences. 2006; 103(10):3816-3821. doi: https://doi.org/10.1073/pnas.0511287103

30. Belkaaloul K, Chekroun A, Ait-Abdessalam A, Saidi D, \& Kheroua O. Growth, acidification and proteolysis performance of two co-cultures (Lactobacillus plantarum-Bifidobacterium longum and Streptococcus thermophilus-Bifidobacterium longum). African Journal of Biotechnology. 2010; 9(10):1463-1469. doi: https://doi.org/10.5897/ajb09.1090

31. Leroy F, De Vuyst L. Lactic acid bacteria as functional starter cultures for the food fermentation industry. Trends in Food Science \& Technology 2004; 15(2):67-78. doi: https://doi.org/10.1016/j.tifs.2003.09.004

32. Barrangou R, Azcarate-Peril M, Duong T, Conners $S$, Kelly R, \& Klaenhammer T. Global analysis of carbohydrate utilization by Lactobacillus plantarum using cDNA microarrays. Proceedings of the National Academy of Sciences. 2006; 103(10):3816-3821. doi: https://doi.org/10.1073/pnas.0511287103

33. Belkaaloul K, Chekroun A, Ait-Abdessalam A, Saidi D, \& Kheroua O. Growth, acidification and proteolysis performance of two co-cultures (Lactobacillus plantarum-Bifidobacterium longum and Streptococcus thermophilus-Bifidobacterium longum). African Journal of Biotechnology. 2010; 9(10):1463-1469. doi: https://doi.org/10.5897/ajb09.1090

34. Biavati B, Bottazzi V, Morelli L. Probiotics and Bifidobacteria. Novara (Italy): Mofin Alce. 2001; 158.

35. King R, Bignell C. Concentrations of isoflavone phytoestrogens and their glucosides in Australian soya beans and soya foods. Australian Journal of Nutrition and Dietetics. 2000; 57(2):70-78. ISSN : 1032-1322

36. Uzzan M, Abuza T. Critical issues in R\&D of soy isoflavone-enriched foods and dietary supplements. Journal of food science. 2004; 69(3):CRH77-CRH86. doi: https://doi.org/10.1111/j.1365-2621.2004.tb13345.x

37. Savijoki K, Ingmer H, \& Varmanen P. Proteolytic systems of lactic acid bacteria. Applied microbiology and biotechnology. 2006; 71(4):394-406. doi: https://doi.org/10.1007/s00253-006-0427-1

38. Shah N. Bifidobacteria: Characteristics and potential for application in fermented milk products. Milchwissenschaft (Germany). 1997

39. Holzapfel $W$, Haberer P, Geisen R, Björkroth $J, \&$ Schillinger U. Taxonomy and important features of probiotic microorganisms in food and nutrition. The American journal of clinical nutrition. 2001; 73(2):365-373. doi: https://doi.org/10.1093/ajcn/73.2.365s

40. Poch M, Bezkorovainy A. Growth-enhancing supplements for various species of the genus Bifidobacterium. Journal of dairy science. 1988; 71(12): 3214-3221. doi: https://doi.org/10.3168/jds.s0022-0302(88)79926-9

41. Tsangalis D, Ashton J, McGill AEJ \& Shah N. Enzymic transformation of isoflavone phytoestrogens in soymilk by $\beta$ glucosidase-producing doi: https://doi.org/10.1111/j.1365-2621.2002.tb08866.x

42. Setchell K, Brown N, Desai P, Zimmer-Nechemias L, Wolfe B, Brashear W. et. al. Bioavailability of pure isoflavones in healthy humans and analysis of commercial soy isoflavone supplements.The Journal of nutrition. 2001; 131(4):1362S1375S. doi: https://doi.org/10.1093/jn/131.4.1362s

43. Setchell K. Absorption and metabolism of soy isoflavones-from food to dietary supplements and adults to infants. The Journal of nutrition. 2000; 130(3):654S-655S. doi: https://doi.org/10.1093/jn/130.3.654s

44. You H, Ahn H, Kim J, Wu Q, \& Ji G. High expression of $\beta$-glucosidase in Bifidobacterium bifidum BGN4 and application in conversion of isoflavone glucosides during fermentation of soy milk. J. Microbiology \& Biotechnology. 2015; 25(4):469-478. doi: http://dx.doi.org/10.4014/jmb.1408.08013

\section{Received 18.11.2020}

Reviewed 02.02.2021

\section{Revised 22.05.2021}

Approved 24.06.2021

\section{Cite as Vancouver Citation Style}

Trufkati L., Kaprelyants L., Pozhitkova L. Biotechnology of soya multi-component functional ingredients. Grain products and mixed fodder's, 2021; 21 (2, 82): 28-38. DOI https://doi.org/10.15673/

\section{Cite as State Standard of Ukraine 8302:2015}

Biotechnology of soya multi-component functional ingredients. / Trufkati L. et al. // Grain Products and Mixed Fodder's. 2021. Vol. 21, Issue 2 (82). P. 28-38. DOI https://doi.org/10.15673/

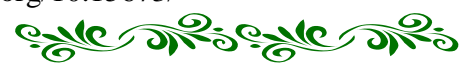

